\title{
СОЦАЛЬНА ВІДПОВІДАЛЬНІСТЬ ОРГАНІВ МІСЦЕВОГО САМОВРЯДУВАННЯ ЯК КРОК ДО РОЗВИТКУ ГРОМАДЯНСЬКОГО СУСПІЛЬСТВА (на прикладі Миколаївського району)
}

Kостєва T. Б., канд. пед. наук, доцент, Інститут державного управління, Чорноморський національний університет імені Петра Могили, м. Миколаїв, Україна

Файчук О. Л., канд. пед. наук, доцент, Інститут державного управління, Чорноморський національний університет імені Петра Могили, м. Миколаїв, Україна

У статті розглянуто теоретичні та практичні аспекти діяльності органів місцевого самоврядування у сучасний період розвитку украӥнського суспільства, розкрито сутність та значення сочіальної відповідальності в управлінні на місиях, а також значення головних аспектів у становленні та розвитку громадянського суспільства.

Зазначено практику розвинених краӥн світу, щзо дає змогу побачити значну різноманітність способів організації місиевого самоврядування. Визначено особливості соціальної відповідальності у період децентралізачіï.

На основі аналізу практичної діяльності органів місчевого самоврядування Миколаӥвського району з'ясовано низький рівень становлення інституту сочіальної відповідальності, щзо не виправдовує стратегічного плану щзодо розвитку європейських цінностей у побудові громадянського суспільства через призму взаємодії громади та місиевої влади.

Авторами вказується на необхідності використовувати досвід сільських рад, ОТГ, які мають яскравий приклад всезадоволеності громади розвитком сіл, загальним благоустроєм та орієнтацією на 
кожну особистість. Наголошено щзо спеціальні принциипи співпрацุi між Україною та СС покликані на регулювання відносин в межах різних галузей.

Обгрунтовано завдання щодо становлення та розвитку громадянського суспільства через призму чіткої сочіальної відповідальності органів місиевого самоврядування перед громадою та суспільства загалом.

Ключові слова: місиеве самоврядування; децентралізачія; соиіальна відповідальність; громадянське суспільство; європейські иінності.

Постановка проблеми у загальному вигляді. Сучасний суспільно-політичний розвиток нашої держави вимагає нового розуміння змісту діяльності органів місцевого самоврядування. Вони виступають однією з активних форм участі громадян в управлінні суспільними справами. Саме органи місцевого самоврядування покликані представляти та захищати інтереси відповідних територіальних громад, нести відповідальність за свою діяльність або бездіяльність перед членами громади. За цих умовах особливої актуальності набувають питання соціальної відповідальності органів місцевого самоврядування. Адже якість їх управління залежить від спроможності підпорядковувати свою діяльність інтересам громади, встановлювати партнерські відносини, забезпечувати відкритість та баланс між економічними та соціальними цілями, постійно розвиватись і вдосконалюватись. Подальше зміцнення інституту місцевого самоврядування зумовлюють об'єктивну потребу дослідження сутності й особливостей соціальної відповідальності органів місцевої влади, розробки конкретних рекомендацій щодо практичного вирішення нагальних проблем.

Аналіз останніх досліджень і публікацій. Питання щодо розбудови громадянського суспільства в Україні, розвитку місцевого самоврядування, впровадження європейських стандартів, концепції соціальної відповідальності набули активного розгляду в науковій літератури. Зокрема, висвітлюються питання історії і практики місцевого самоврядування в Україні (В. Смельянов, Л. Бабич, С. Ба- 
лацький, М. Багмет, Ю. Палагнюк, О. Штирьов та ін.), питання становлення місцевого самоврядування в Україні (В. Погорілка, М. Пухтинського, А. Ткачука), організаційно-управлінський аспект формування структури місцевого самоврядування в Україні (В. Бабаєв, О. Бобровська, С. Болдирєв, А. Дєгтяр, А. Гошко, Я. Жовнірчик, А. Мерзляк, Ю. Молодожен, В. Огаренко, Р. Плющ, А. Ткачук та ін.), проблеми соціальної відповідальності органів місцевої влади (А. Колповська, А. Рижко, Н. Гончарук, Б. Качали та ін.), питання впливу державної політики на формування соціальної відповідальності (О. Кузьмін, О. Пирог та ін.).

Формулювання цілей статті (постановка завдання). На основі теоретичного аналізу та проведених бесід з громадами та сільськими головами Миколаївського району, охарактеризувати сучасний стан діяльності органів місцевого самоврядування України на прикладі Миколаївського району.

Виклад основного матеріалу дослідження. Поняття соціальної відповідальності для вітчизняної науки не є новим. Проте його опредметнення в діях представників влади викликає ряд протиріч. Реалізація соціальної відповідальності в діях державних органів влади специфічна залежно від рівня їх діяльності. Саме від органів місцевого самоврядування населення очікує більшої публічності та дієвості. Адже вони сприймаються представниками громади, як люди, яких було обрано з метою захисту їх прав та інтересів саме на місцях.

Сутність поняття місцевого самоврядування закріплена в Свропейській Хартії місцевого самоврядування, Конституції України [11], Законі України «Про місцеве самоврядування в Україні» [18].

Місцеве самоврядування - це право і реальна здатність органів місцевого самоврядування регламентувати значну частину публічних справ і управляти нею, діючи в межах закону, під свою відповідальність і в інтересах місцевого населення [18].

В контексті нашого дослідження органи місцевого самоврядування визначаються як місцеві органи виконавчої влади, які обираються мешканцями громади. Згідно зі ст. 2. Закону України «Про місцеве самоврядування»: «місцеве самоврядування в Україні - це гарантоване державою право та реальна здатність територіальної 
громади - жителів села чи добровільного об’єднання у сільську громаду жителів кількох сіл, селища, міста - самостійно або під відповідальність органів та посадових осіб місцевого самоврядування вирішувати питання місцевого значення в межах Конституції і законів України» [18]. Система місцевого самоврядування включає: територіальну громаду; сільську, селищну, міську раду; сільського, селищного, міського голову; виконавчі органи сільської, селищної, міської ради; старосту; районні та обласні ради, що представляють спільні інтереси територіальних громад сіл, селищ, міст; органи самоорганізації населення.

Практика розвинених країн світу дає змогу побачити значну різноманітність способів організації місцевого самоврядування. Так, прийнято вважати, що в Свропі історично сформувались дві моделі місцевого самоврядування:

- Англосаксонська (Великобританія, Нова Зеландія та ін.), яка характеризується високим ступенем автономії органів місцевого самоврядування, виборністю, відсутністю спеціальних державних уповноважених на місцях та місцевих адміністрацій. Тобто органи місцевого самоврядування в рамках закону вирішують ті питання, які не належать до компетенції держави. Державний контроль здійснюється лише у формі судового контролю.

- Континентальна модель (Франція, Бельгія, Італія та ін.) характеризується спільністю дій місцевого самоврядування і органів державної влади, при чому місцеве самоврядування займає підлеглу позицію і має обмежену автономію.

Деякі дослідники зауважують на існуванні ще двох моделей:

- «ліберійської» (Іспанія та Португалія), яка характеризується існуваням на всіх рівнях адміністративно-територіального устрою держави виборних представницьких органів та головних посадових осіб місцевого самоврядування, що очолюють виконавчі органи. Така обрана посадова особа затверджується урядом як представник держави в адміністративно-територіальній одиниці з правом контролю за діяльністю представницького органу.

- «радянська» модель, яка діяла передусім у Радянському Союзі» і мала основоположний принцип повновладдя представниць- 
ких органів на відповідній території. Місцеві представницькі органи вважаються органами державної влади, водночас як їх виконавчі органи - місцевими органами державного управління [14].

Разом 3 тим у більшості країн Європи (Німеччина, Австрія та ін.) можна спостерігати поєднання цих двох моделей. Аналізуючи цю тенденцію, дослідники зазначають: «Порівнюючи англосакську і континентальну моделі місцевого самоврядування, слід мати на увазі, що в демократично розвинутих країнах відмінності між цими двома моделями не носять принципового характеру. Їх сучасна форма, яка фактично є результатом проведених реформ місцевого самоврядування, дозволяє говорити про певне зближення зовсім відмінних одна від одної муніципальних систем» [9].

В Україні становлення інституту місцевого самоврядування відбувається на основі вивчення закордонного досвіду. Особливо цінним є досвід Польщі у проведенні реформи місцевого самоврядування, яка пішла шляхом децентралізації та укрупнення адміністративно-територіальних одиниць. Адже, на думку багатьох експертів, саме досвід Польщі є близьким для України, з урахуванням подібних стартових можливостей обох країн. Як зазначає В. Толкованов місцеве самоврядування в Польщі має ряд характеристик: обрання місцевої влади шляхом демократичних виборів; надання статусу юридичної особи представникам місцевої влади, що дає їй право самостійно прийняти рішення та розпоряджатись майном, затверджувати власний бюджети та розпоряджатись фінансовими ресурсами у рамках законодавства щодо публічних фінансів тощо [20].

Реформа децентралізації у цій країні сприяла зміцненню ефективності діяльності місцевої влади та підвищенню рівню участі громадян у прийнятті рішень. Сьогодні в Польщі утворено трирівневу структуру місцевого самоврядування: гмін (займаться вирішенням публічних справ місцевого самоврядування), повітів (вирішують ті публічні питання, які не входять до компетенції гмін), воєводств (є представники державноії влади та здійснють контрольно-наглядову функцію по відношенню до гмін та повітів). Загалом в Польщі налічується 16 воєводств та 308 повітів [9]. Основною одиницею місцевого самоврядування виступає гміна, яка несе відповідальність 
за: дитячі садки та школи (саме орган місцевого самоврядування виступає власником школи та відповідає за програму навчання, iii наповненя та зміст); комунальне господарство (гміни вирішують питання щодо енергопостачання, водопостачання, переробки відходів, утримання комунальних споруд); соціальних захист населення (за кошти місцевого бюджету здійснюється лікування безробітних громадян і т.п.); функціонування бібліотек та закладів культури; побудову та утримання доріг; вирішення земельних питань (гміна виступає власником всіх земельних ділянок, окрім стратегічно важливих об'єктів і має право вирішувати питання щодо використання цих ресурсів).

Надзвичайну ефективність органи місцевого самоврядування Польщі показали саме у вирішенні питань зайнятості населення та розвитку комунальної інфраструктури (ремонт доріг, покращення доступу до базових послуг, подолання бідності тощо).

Реалізація публічної влади органами, уповноваженими наразі представляти інтереси народу України, не може відбуватися без чіткої і конкретної системи відповідальності органів влади. Представницький орган місцевого самоврядування, як суб'єкт відповідальності - виборний орган (рада), який складається 3 депутатів і відповідно до закону наділяється правом представляти інтереси територіальної громади і приймати від їі імені рішення.

Активна реалізація концепції соціальної відповідальності в Україні розпочалась у 2000-х роках. Рушійною силою для цього стала євроінтеграційна політика нашої держави. Саме досвід європейських країн, таких як Данія, Швеція, Фінляндія, Франція, Німеччина, свідчить, що соціальна відповідальність органів влади $\epsilon$ реальним інструментом підвищення добробуту громади, стимулювання іiї економічного та культурного розвитку.

У 2014 р. відбулось підписання Угоду про асоціацію між Україною та Європейським Союзом. Обов'язковим елементом державних перебудов в рамках цього процесу є реформа публічної служби. У першому розділі та преамбулі Угоди про асоціацію йдеться про те, що Україна засвідчує свою відданість принципам демократії, верховенства права, високому рівню урядування, дотриманню прав 
і свобод людини та усім засадам ринкової економіки. При цьому надзвичайно важливими є принципи, на яких передбачено вибудовувати партнерські взаємини з СС, які полягають у взаємній довірі, відповідальності, сприяння сталому розвитку й зеленій економіці [17]. Слід зазначити, що внутрішня і зовнішня політики України загалом мають підпорядковуватись засадам верховенства права. Такі принципи співпраці можна віднести до загальних. Немає сумнівів, що загальні принципи здійснюють неабиякий вплив на реформування державного управління, зокрема, сприяють загальному поліпшенню адміністрування, боротьбі з корупцією, підвищенню кваліфікації урядовців тощо. Поряд із загальними принципами, які вплинуть не лише на сферу державного управління, існують і більш спеціальні, що стосуються окремих сфер державного життя [20].

Спеціальні принципи співпраці між Україною та СС покликані на регулювання відносин в межах різних галузей. Наприклад, сюди відносять принципи чесності, моралі, обміну інформацією, адміністративної співпраці тощо. Надзвичайно важливе значення надають принципу прозорості, який згадується по відношенню до різних типів галузевої співпраці між Україною та СС [17].

На регіональному рівні в рамках Євроінтеграції очікується вдосконалення системи державного управління через проведення децентралізації. Остання передбачає розширення функцій місцевого самоврядування, зокрема, таких, що стосуються фінансів. Станом на кінець 2017 р. більше як 90 \% територіальних громад мали дотаційні бюджети, при цьому державні дотації складали більше як 70 \% від їх загального розміру. Подібна ситуація призвела до нездатності місцевого самоврядування повною мірою виконувати покладені на нього функції. Після вживання відповідних заходів в межах децентралізації відбулось надання більших фінансових повноважень місцевим громадам. Станом на кінець 2018 р. простежується зростання доходів місцевих бюджетів на 38,3 \%, що є більшим, ніж за аналогічний період 2017 p. Ці та інші показники свідчать про те, що децентралізація вже на початкових етапах сприяє формуванню ефективної системи місцевого самоврядування та поліпшенню фінансового стану територіальних громад в цілому та окремих їх мешканців [6]. 
Посилення антикорупційних заходів є ще одним напрямком змін у сфері публічної служби відповідно до Угоди про асоціацію 3 Європейським Союзом. Задля цього створено Єдиний електронний реєстр декларацій про майно, доходи, витрати та зобов'язання фінансового характеру державних службовців. Ще одним кроком у цьому напрямку стало відкриття даних майнового реєстру та кінцевих вигодонабувачів юридичних осіб. У галузі економічної політики передбачено об'єднання податкової та бухгалтерської звітної документацій, і також узгоджено фінансову звітність у відповідності до міжнародних стандартів.

На думку Ю. Горемикіной Ю. та Т. Калашніковой, успішна реалізація принципу соціальної відповідальності органами місцевого самоврядування суттєво впливає на імідж органів влади загалом, оскільки за своїм статусом перші є достатньо наближеними до конкретного громадянина та його потреб, та саме завдяки їх роботі у нього формуються певні судження про функціонування владних структур [8]. За умови наявності реального діалогу між місцевим органом влади та громадянами, у ході якого враховуються думки всіх сторін стосовно організації життя у громаді та вирішення актуальних для неї питань, слід констатувати, що місцевий орган влади виявляє і несе соціальну відповідальність.

Водночас А. Колповська у своєму дослідженні акцентує увагу на тому, що соціальна відповідальність особи, яка $є$ представником органів місцевого самоврядування проявляється через усвідомлення обов'язку перед суспільством, бажання допомагати громаді, якісно виконувати свою роботу [10]. Сучасні дослідники виділяють ряд складових соціальної відповідальності. До них можна віднести: спрямованість на сталий розвиток, впровадження інновацій, зниження корупції, розвиток громадянського суспільства, територіальний розвиток, поліпшення екологічного стану, підвищення рівня життя жителів громади, сприяння розвитку малого та середнього бізнесу та ін.

О. Кузьмін та О. Пирог, проаналізувавши досвід становлення соціальної відповідальності в країнах ЄС, запропонували державні механізми розвитку соціальної відповідальності в Україні [13]. 
Основними напрямками розвитку соціальної відповідальності $€$ : підвищення інформованості населення з питань соціальної відповідальності, що можливе шляхом прийняття відповідних законодавчих ініціатив, надання грантів або кредитів на розвиток цієї сфери, проведення наукових конференцій та семінарів, розробки інформаційних ресурсів (брошури, сайти); підвищення відкритості дій органів місцевого самоврядування на основі введення законодавчо закріпленої звітності перед громадою, розробки інструкції щодо технології звітування та механізмів використання санкцій за невиконання цієї умови; підвищення ефективності діяльності громадських організацій шляхом делегування суспільних послуг; побудова партнерських відносин між місцевим самоврядуванням та бізнесом з метою спільної розробки та реалізації суспільно важливих проектів, забезпечення соціально-економічного розвитку громади тощо.

Разом 3 тим етап становлення інституту соціальної відповідальності в діяльності органів місцевого самоврядування Миколаївського району в більшості випадків не виправдовує стратегічного плану щодо розвитку європейських цінностей у побудові громадянського суспільства через призму взаємодії громади та місцевої влади.

На основі аналізу результатів проведених бесід серед населення та власного спостереження, аналізу документів, таких як: субвенцій - надходження бюджету до сільських рад, протоколів кількості та якості проведених сесій та прийнятих рішень, існування офіційних веб-порталів чи груп розповсюдження та доступу до публічної інформації, можемо скласти сьогоденний «портрет» ефективності функціонування органів місцевої влади Миколаївського району Миколаївської області. Окрім цього, про невтішний загальний стан розвитку з точки зору надходжень загального фонду до зведених бюджетів Миколаївської області, можна побачити 3 наведених нижче діаграм, в кожній з яких визначено місце Миколаївського району. 
Діаграма 1

\section{Надходження загального фонду до зведених бюджетів районів Миколаївської області}

\section{Приріст/зниження надходжень загального фонду до зведених бюджетів районів Миколаївської області за січень-лютий 2018/2019 років, \%, млн грн}

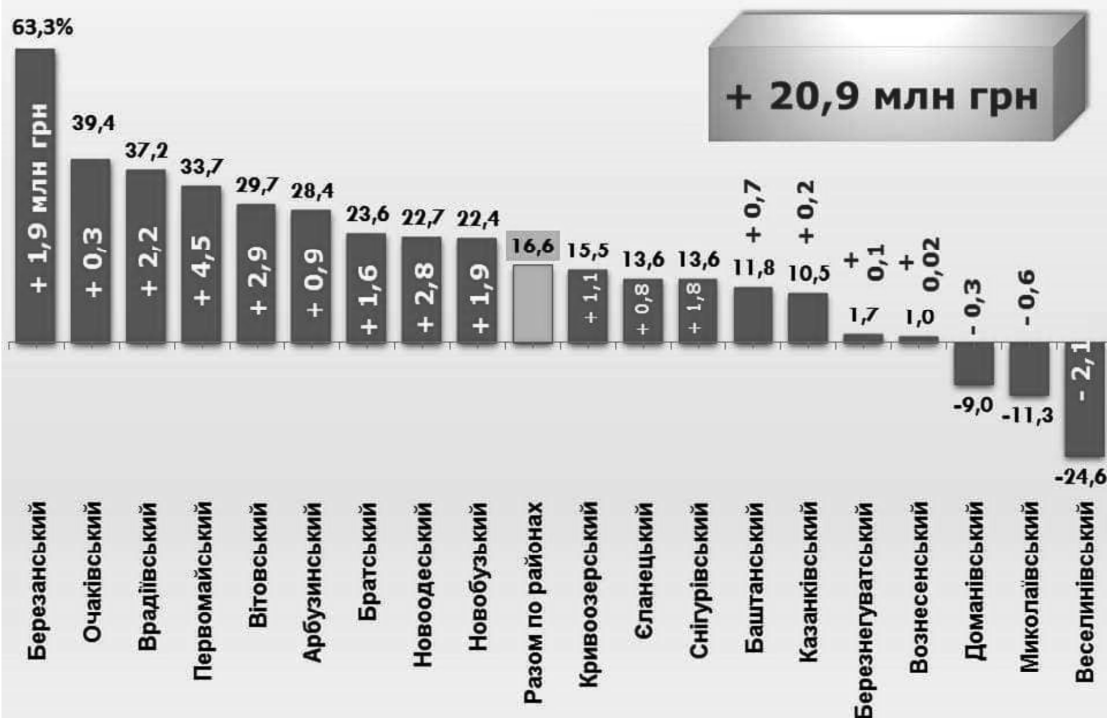

За цими показниками бачимо місце Миколаївського району в рейтингу приросту доходів загального фонду, який $\epsilon$, на жаль, негативним. Окрім цього, розглядаючи не фінансові сторони існування органів місцевого самоврядування, виділяємо Петрівську сільську раду Миколаївського району, яка має у своєму підпорядкуванні три села: Зелений Яр, Петрівка, Карлівка. Зараз це сільська рада, яка порушує права громадян, виходить за межі своїх повноважень та не виконує своїх норм діяльності по відношенню до розвитку сіл. За нашими власними спостереженнями протягом 6 місяців громада не отримала жодної повноцінної відповіді на численні запити щодо питань, які їх цікавили, а саме: час, коли буде наданий звіт про завершений 2018 рік, бюджетний звіт 2017-2018 року, дати проведен- 
ня сесій та питань, які вирішуються щодо того чи іншого напряму 3 розвитку села, пропозиції щодо створення веб-сайту Петрівської сільради для головних та актуальних питань громади; питання ремонту доріг та їх тверде покриття тощо.

Діаграма 2

Приріст доходів загального фонду Миколаївської області

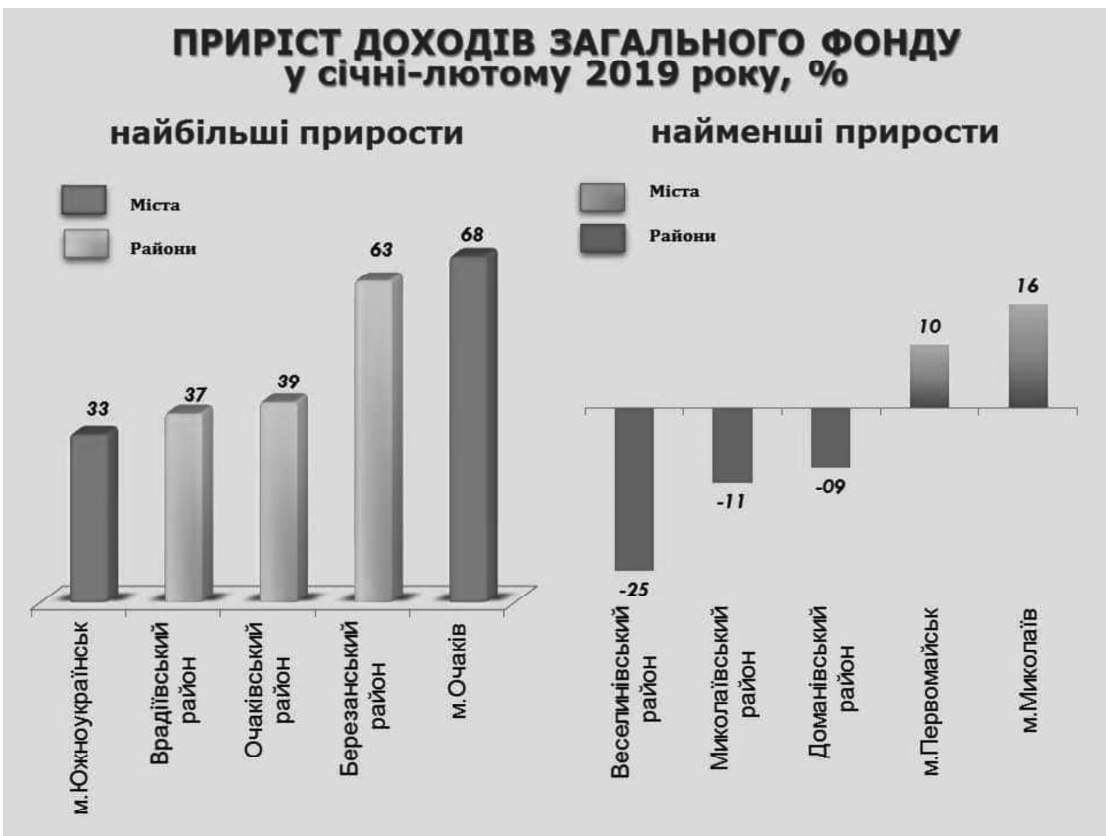

На базі зазначених законів «Про органи місцевого самоврядування» та про «Доступ до публічної інформації» на базі сільських рад, створюються офіційні чи неофіційні ініціативні групи, які намагаються допомогти населенню досягнути питань справедливості та відновити взаємодію між органами місцевого самоврядування та громадою. Практика таких груп нетривала, оскільки більшість з них зазнає поразки або відступає через масову корупцію на рівні району, в тому числі й судову владу. 
Згідно з Законом України «Про місцеве самоврядування в Україні»: орган та посадові особи місцевого самоврядування $є$ підзвітними, підконтрольними і відповідальними перед територіальними громадами. Вони періодично, але не менш як два рази на рік, інформують населення про виконання програм соціально-економічного та культурного розвитку, місцевого бюджету, з інших питань місцевого значення, звітують перед територіальними громадами про свою діяльність [18]. Але за результатами аналізу бесід в жодній $з$ громад сільських рад, таких як: Кривобалківська, Петрівська, Веснянська, означені заходи не відбуваються.

Ініціативні групи у разі порушення їх права доступу до публічної інформації офіційно звертаються до Уповноважених справ людини, але якісного результату це не дає, все завершується адміністративним покаранням, після чого дуже часто ситуації з недоступом громади до публічної інформації продовжуються.

Законом України «Про місцеве самоврядування в Україні» зазначається, що «територіальна громада у будь-який час може достроково припинити повноваження органів та посадових осіб місцевого самоврядування, якщо вони порушують Конституцію або закони України, обмежують права і свободи громадян, не забезпечують здійснення наданих їм законом повноважень» [18]. Але реалізація означеного закону у разі ряду порушення прав громади, корупції, фінансових махінаціях, перевищення своїх повноважень, прийняття усіх рішень без згоди громади є неможливою, якщо громада $є$ соціально неактивною, не відповідає нормам громадянського суспільства.

Ще Платон казав: «В покарання за громадянську пасивність люди отримують владу злодіїв» [10]. Значна частина сільських, селищних рад - саме той яскравий приклад отримання неповноцінної влади, яка продовжує розвиватися через пасивність громади.

Дещо протилежного значення має розвиток сіл, які входять до ОТГ Радсад. У процесі комунікативної взаємодії, відзначаємо загальну задоволеність жителів сіл щодо розвитку та благоустрою території проживання, мінімально необхідною взаємодією з громадою та звітуванням щодо витрачених бюджетних коштів та пророблену 
роботу. В свою чергу, Нечаянське та Радсадівське ОТГ показує приклад іншим селам Миколаївського району щодо участі в проектах, які дозволяють отримувати додаткове фінансування на розвиток вагомих напрямів життєдіяльності (будинки культури, стадіони, школи, дитячі садки).

Відповідно, для розвитку органів місцевого самоврядування Миколаївського району до зразка європейського стандарту, варто визначити ряд пріоритетних напрямів щодо корекції виникаючих незначних проблем та повної ліквідації факторів, руйнуючих право сільських, селищних громад, ОТГ до повноцінного об'єму використання прав громадян на життя у високорозвинених суспільних громадах європейського зразка.

Для задоволення означеної потреби варто скласти, на початковому етапі, програму мінімум (мінімальна програма дій), яка має містити наступну мету: зміцнення засад громадянського суспільства розвитку демократії; удосконалення правових засад місцевого самоврядування сільських, селищної, міської рад району; зміцнення матеріально-фінансової основи місцевого самоврядування; розвиток ініціативи населення у вирішенні питань місцевого значення; поліпшення умов для забезпечення життєдіяльності та соціального захисту населення, забезпечення якісного надання громадських послуг населенню.

Відповідно до мети мають бути спрямовані наступні завдання: сприяння формуванню економічно-достатніх територіальних громад району; удосконалення управління об’ єктами права комунальної власності та спільної власності територіальних громад району; надання методичної допомоги сільським, селищній та міській радам району; підвищення професійного рівня посадових осіб органів місцевого самоврядування, забезпечення підготовки кадрів для цих органів.

Варто виокремити проведення просвітницької діяльності $з$ питань розвитку місцевого самоврядування району, а саме:

- святкування державних та професійних свят, ювілеїв та подій районного значення. Придбання необхідної атрибутики для проведення цих заходів (вітальні листівки, цінні подарунки, призи, корзини квітів, траурні вінки, тощо); 
- залучення громадських організацій, наукових установ, жителів сіл, селища і міста до процесу розвитку місцевого самоврядування; коштів Державного бюджету України, місцевих бюджетів та інших джерел не заборонених законодавством України;

Відповідно до означених завдань, ми пропонуємо використовувати досвід сільських рад, ОТГ, які мають яскравий приклад всезадоволеності громади розвитком сіл, загальним благоустроєм та орієнтацією на кожну особистість, а саме:

- удосконалення надання адміністративних і громадських послуг населенню;

- створення фонду підтримки перспективних ідей та ініціатив щодо місцевого розвитку;

- створення центру досягнень територіальних громад;

- щорічне проведення районного огляду сіл, селища та міста району щодо благоустрою, підтримання громадського порядку та ін., повноцінного виконання своїх обов'язків голови чи старости по відношенню до своїх посадових обов'язків та взаємодії з громадою;

- проведення районного конкурсу в номінації: «Кращий сільський, селищний та міський голова»;

- організація проведення конкурсу серед молоді району на кращу працю з удосконалення роботи і вирішення проблем місцевого самоврядування нашого району;

- зміцнення власної дохідної бази органів місцевого самоврядування та підвищення ролі місцевих податків та зборів у формуванні доходів місцевих бюджетів району;

- розроблення та реалізація проекту «Участь молоді в розвитку місцевого самоврядування району»;

- забезпечення публікацій в засобах масової інформації про роботу та вирішення проблем у сфері районної, міської, селищної та сільських рад району;

- сприяння співробітництву по укладенню та виконанню угод органів місцевого самоврядування району із органами місцевого самоврядування інших регіонів країни, іноземних держав, міжнародними організаціями та фондами з питань розвитку місцевого самоврядування, дружби та культурно-просвітницької діяльності; 
- проведення капітального та поточного ремонтів та здійснення інших видатків на об’єкти, що знаходяться у спільній власності територіальних громад Миколаївського району та перебувають на балансі Миколаївської районної ради;

- навчання та підвищення кваліфікації посадових осіб органів місцевого самоврядування, голів постійних комісій районної ради, представників депутатського корпусу;

- участь у міжнародних, всеукраїнських та обласних конкурсах проектів і програм розвитку місцевого самоврядування, співфінансування їхніх переможців та призерів;

- окремі заходи на виконання розпоряджень та доручень голови, зокрема: круглі столи, конференції, семінари, офіційні зустрічі 3 керівниками міжнародних установ, організацій, фондів, проектів та програм, керівниками органів місцевого самоврядування, у тому числі інших регіонів, офіційні прийоми головою районної ради, збори, фестивалі, інші заходи за участю представників органів місцевого самоврядування та громадськості;

- нагородження грамотами, подяками, нагородами, відзнаками, вітальними листівками та іншими подарунками з нагоди професійних, державних свят, пам'ятних дат та днів народжень.

- розробка сайту кожної сільської ради, ОТГ, який буде містити вичерпну інформацію про діяльність органів місцевого самоврядування;

- фінансова звітність не лише перед органами державної влади, а й перед жителями громади раз у квартал. Форма звітності, залежно від вимог громади - на сайті, письмові звіті у місцевих газетах, усно перед мешканцями сіл, що забезпечить можливість діалогу;

- проведення щоквартального моніторингу нагальних проблем громади (на основі опитування або письмових побажань жителів ОТГ представники місцевого самоврядування визначають ті реальні проблеми, вирішення яких покращить життєдіяльність громади).

Висновки. Сучасні тенденції розвитку сіл та ОТГ Миколаївського району, на нашу думку, відрізняються від тих цінностей та 
стандартів європейського характеру у побудові громадянського суспільства та соціальної відповідальності на рівні місцевого самоврядування, які проголошувала влада України при взятті курсу на децентралізацію. Тому вважаємо за доцільне, у подальших наукових дослідженнях проаналізувати основні причини недоліків роботи місцевої влади, можливості співіснування громади при об'єднанні та визначити чіткі практичні рекомендації щодо формування та розвитку громадянського суспільства серед громади Миколаївського району на основі чітких європейських стандартів існування органів влади.

\section{Стаття надійшла до редакції: 23.12.2018}

\section{SOCIAL RESPONSIBILITY OF LOCAL AUTHORITIES AS A STEP TO THE DEVELOPMENT OF CIVIL SOCIETY (on the example of Mykolayiv district)}

Tetiana Kostieva, $\mathrm{PhD}$ in Pedagogy, Associate professor Black Sea National University of Petro Mohyla Mykolaiv, Ukraine

Olena Faichuk, PhD in Pedagogy, Associate professor Black Sea National University of Petro Mohyla Mykolaiv, Ukraine

The article deals with the theoretical and practical aspects of the activities of local governments in the modern period of Ukrainian society development, discloses the essence and importance of social responsibility in the field management, as well as the importance of the main aspects in the formation and development of civil society.

The practice of the developed countries of the world is indicated, it allows to see a considerable variety of ways of organizing local selfgovernance. The features of social responsibility during the period of decentralization are determined.

On the basis of the analysis of the practical activities of the local self-government bodies of the Nikolaevsky district, a low level of 
establishment of the social responsibility institute is established, it does not justify a strategic plan for the development of European values in building a civil society through the prism of interaction between society and government.

The authors point out the need to use the experience of village councils, OTGs, which have a vivid example of community satisfaction with the development of villages, general improvement and orientation to each individual. It is noted that the special principles of cooperation between Ukraine and the EU are called upon to regulate relations within the various branches.

Based on the analysis of the practical activities of the Mykolaiv local government bodies, the low level of the establishment of the social responsibility institution has been determined, which does not justify the strategic plan for the development of European values in the construction of civil society through the prism of the interaction of the community and local authorities.

Reasonable goals are the formation and development of civil society through the prism of the clear social responsibility of local selfgovernment bodies to society and society as a whole.

Keywords: local self-government, decentralization, social responsibility, civil society, European values

\section{Received: 23.12 .2018}

\section{References}

1. Bahmet, M.O. (2009). Tsinnist mistsevoho samovriaduvannia yak demokratychnoi formy detsentralizatsii derzhavno-vladnykh povnovazhen [The value of local self-government as a democratic form of decentralization of state power powers]. Naukovi pratsi : Naukovo-metodychnyi zhurnal. Derzhavne upravlinnia, 112, 33-37 [in Ukrainian].

2. Chykarenko, I. A. (2016), Teoretyko-metodolohichni zasady formuvannia systemy upravlinnia innovatsiinym rozvytkom terytorialnym hromad [Theoretical and methodological principles of formation of the system of management of innovative development of territorial communities]. Extended 
abstract of candidate's thesis. Zaporizhzhia: Klasychnyi pryvatnyi universytet [in Ukrainian].

3. Demkova, M. S. \& Fihel, M. V. (2004). Dostup do informatsii ta elektronne uriaduvannia [Access to information and e-government]. Kyiv : Tsentr polityko-pravovykh reform. Fakt [in Ukrainian].

4. Detsentralizatsiia v Ukraini: zakonodavchi novatsii ta suspilni spodivannia [Decentralization in Ukraine: legislative innovations and public expectations]. (2015). Kyiv : Instytut zakonodavstva Verkhovnoi Rady Ukrainy [in Ukrainian].

5. Detsentralizatsiia vlady na osnovi krashchykh inozemnykh praktyk ta ukrainskykh zakonodavchykh initsiatyv [Ecentralization of power based on best foreign practices and Ukrainian legislative initiatives]. (n.d.). Retrieved from http://www.uiip.org.ua/wp-content/uploads/2015/05/pdf [in Ukrainian].

6. Emelyanov, V.M. \& Shulga A.A. (2017). Normatyvno-pravove zabezpechennia reformuvannia mistsevoho samovriaduvannia ta obiednannia terytorialnykh hromad $\mathrm{v}$ Ukraini [Regulatory support the reform of local self-governments and associations local communities in Ukraine]. Naukovi pratsi : Naukovo-metodychnyi zhurnal. Derzhavne upravlinnia, 290, 48-58 [in Ukrainian].

7. Evtushenko, O. N. (2008). Demokratyzatsiia derzhavnoi vlady i mistsevoho samovriaduvannia na pryntsypi subsydiarnosti: dosvid Nimechchyny [Democratization of state power and local self-government on the principle of subsidarisation: Germany's experience]. Naukovi pratsi : Naukovometodychnyi zhurnal. Politolohiia, 93, 76-81[in Ukrainian].

8. Horemykina, Yu.V. \& Kalashnikova, T.M. (2018). Spetsyfika sotsialnoi vidpovidalnosti orhaniv mistsevoho samovriaduvannia [Specifics of social responsibility of local self-government bodies]. Prychornomorski ekonomichni studii, 25, 158-163 [in Ukrainian].

9. Hrobova, V.P. (2015). Systema mistsevoho samovriaduvannia v Polshchi: perspektyvy vykorystannia dosvidu $\mathrm{v}$ Ukraini [The system of local self-government in Poland: prospects for using experience in Ukraine]. Naukovyi visnyk Uzhhorodskoho natsonalnoho universytetu. Seriia Pravo, 31, 78-82 [in Ukrainian].

10. Kolpovska, A.M. (2014). Rozvytok kontseptsii sotsialnoi vidpovidalnosti $\mathrm{v}$ munitsypalnomu upravlinni [Development of the concept of social responsibility in municipal governance]. Extended abstract of candidate's thesis. Dnipro: DRIDU NADU [in Ukrainian]. 
11. Konstytutsiia Ukrainy [The Constitution of Ukraine]. (1996, June 28). Vidomosti Verkhovnoi Rady Ukrainy - Bulletin of Verkhovna Rada of Ukraine. Kyiv: Parlam. vyd-vo [in Ukrainian].

12. Kontseptsiia reformy mistsevoho samovriaduvannia i terytorialnoi orhanizatsii vlady v Ukraini [The Concept of Reform of Local Self-Government and Territorial Organization of Power in Ukraine]. (n.d.). Retrieved from http:// zakon3.rada.gov.ua/laws/show/333- 2014-\%D1\%80 [in Ukrainian].

13. Kuzmin, O.E. \& Pyroh, O.V. (2014). Instrumenty derzhavnoi polityky iz formuvannia sotsialno vidpovidalnoi povedinky v konteksti modelei staloho rozvytku [Government policy tools for building socially responsible behavior in the context of sustainable development models]. Dnipropetrovsk: NHU [in Ukrainian].

14. Munytsypalnыe systemы zarubezhnыkh stran [Municipal systems of foreign countries]. (n.d.). Retrieved from http://www.dvgups.ru/METDOC/ CGU/PRAVO/M_PRAVO [in Russian].

15. Palagnyuk Yu.V. (2014). Derzhavna yevrointehratsiina polityka Ukrainy: teoriia, metodolohiia, mekhanizmy [The European Investment Policy Policy of Ukraine: Theory, Methodology, Mechanism]. Mykolaiv: Vyd-vo ChDU im.Petra Mohyly [in Ukrainian].

16. Pro Stratehiiu staloho rozvytku «Ukraina - 2020» [About the Strategy of Sustainable Development «Ukraine 2020»]. (2015, January 12). Retrieved from http://zakon0.rada.gov.ua/laws/show/5/2015 [in Ukrainian].

17. Uhoda pro asotsiatsiiu mizh Ukrainoiu, $\mathrm{z}$ odniiei storony, ta Yevropeiskym Soiuzom, Yevropeiskym spivtovarystvom $\mathrm{z}$ atomnoi enerhii i yikhnimy derzhavamy-chlenamy, $\mathrm{z}$ inshoi storony [Association Agreement between Ukraine, on the one hand, and the European Union, the European Atomic Energy Community and their Member States, on the other hand]. (n.d.). Retrieved from https://zakon.rada.gov.ua/laws/show/984_011 [in Ukrainian].

18. Zakon Ukrainy « Pro mistseve samovriaduvannia v Ukraini» [Law of Ukraine «On Local Self-Government in Ukraine»]. (n.d.). Retrieved from https:// zakon.rada.gov.ua/laws/show/280/97-\%D0\%B2\%D1\%80 [in Ukrainian].

19. Zakon Ukrainy «Pro zapobihannia koruptsii» [Law of Ukraine «On Prevention of Corruption»]. (n.d.). Retrieved from http://zakon4.rada. gov.ua/ laws/show/1700 18 [in Ukrainian].

20. Zvit pro vykonannia uhody pro asotsiatsiiu mizhUkrainoiu ta Yevropeiskym Soiuzom za 2017[Report on the implementation of the Association Agreement between Ukraine and the European Union for 2017]. (n.d.). Retrieved from http:// zvit_EU_16_02_final.pdf [in Ukrainian]. 


\section{Відомості про авторів / Information about the Authors}

Костсва Тетяна Богданівна: Чорноморський національний університет імені Петра Могили вул. 68 Десантників 10, Миколаїв, 54003, Україна.

Tetiana Kostieva: Black Sea National University of Petro Mohyla: 68 Desantnykiv str. 10, Mykolaiv, 54003, Ukraine.

\section{ORCID.ORG/ 0000-0002-6455-4382}

\section{E-mail: tetyana910@com.ua}

Файчук Олена Леонідівна: Чорноморський національний університет імені Петра Могили вул. 68 Десантників 10, Миколаїв, 54003, Україна.

Olena Faichuk: Black Sea National University of Petro Mohyla: 68 Desantnykiv str. 10, Mykolaiv, 54003, Ukraine.

ORCID.ORG/ 0000-0002-6663-3287

E-mail: Fajchuk@mksat.net 